\title{
HYDROUS LOWER MANTLE: THE WATER SOURCE FOR WET PLUMES?
}

\author{
Konstantin Litasov and Eiji Ohtani \\ Inst. Mineral. Petrol. Econ. Geol., Tohoku University, Sendai, Japan
}

\section{INTRODUCTION}

Recent experimental and theoretical studies suggest that water plays a key role in the geodynamics of the Earth's interior because it significantly affects melting, phase transitions and physical properties of minerals. Ringwood (1977) proposed about $2 \mathrm{wt} \%$ of $\mathrm{H}_{2} \mathrm{O}$ in Earth's source material, assuming Earth was formed from a mixture of $\mathrm{C} 1$ chondrite- and enstatite chondritelike components. Although part of $\mathrm{H}_{2} \mathrm{O}$ or molecular $\mathrm{H}$ may have been lost since the Earth's birth, many data suggest that a considerable amount of water can be stored in the Earth interior.

The upper mantle, transition zone and lower mantle could have different potentials for storing water. Upper mantle is relatively dry. Transition zone should be an important water reservoir due to significant (2-3 wt.\% of $\mathrm{H}_{2} \mathrm{O}$ ) water solubility in wadsleyite and ringwoodite $(\mathrm{Mg}, \mathrm{Fe})_{2} \mathrm{SiO}_{4}$ (e.g. Kohlstedt et al., 1996). Water storage capacity of the lower mantle becomes a matter of debate. At lower temperatures $\left(<1300^{\circ} \mathrm{C}\right)$, superhydrous phase $B$ and phase $G(D / F)$ can accommodate water in the uppermost lower mantle. The lower mantle consists of Mg-perovskite, ferropericlase and Ca-perovskite, however the water solubility of these minerals is poorly studied. Meade et al. (1994) reported results of FTIR measurements of water solubility in $\mathrm{MgSiO}_{3}$-perovskite and documented two pleochroic hydroxyl absorbance peaks at 3423 and $3483 \mathrm{~cm}^{-1}$. Calculation of water content corresponds to 60-70 ppm $\mathrm{H}_{2} \mathrm{O}$. However, Bolfan-Casanova et al. (2000) showed absence of water $\left(<1 \mathrm{ppm} \mathrm{H}_{2} \mathrm{O}\right)$ in $\mathrm{MgSiO}_{3}$-perovskite. Recent data on water solubility in peridotite-related Al-Fe-Mg-perovskite measured by SIMS and FTIR revealed 0.1-0.4 wt $\% \mathrm{H}_{2} \mathrm{O}$ (Murakami et al., 2002). Murakami et al. (2002) also reported 0.3$0.4 \mathrm{wt} \% \mathrm{H}_{2} \mathrm{O}$ in Ca-perovskite and about $0.2 \mathrm{wt} \% \mathrm{H}_{2} \mathrm{O}$ in ferropericlase. These data however may be doubtful on the basis of the recent studies by Bolfan-Casanova et al. (2002), who reported less $20 \mathrm{ppm} \mathrm{H}_{2} \mathrm{O}$ in ferropericlase at $25 \mathrm{GPa}$.

In this contribution we study water solubility in $\mathrm{Mg}$ perovskites (pure, aluminous, and those observed in peridotite and former oceanic crust), Ca-perovskite, and ferropericlase. Using the measured water content we (1) estimate water storage capacity in the Earth's lower mantle and (2) propose role of water in generation of wet mantle plume and transport of lower mantle diamonds to the lithosphere.

The phase relations were determined at 25-26 GPa and the temperature range from 1000 to $1800^{\circ} \mathrm{C}$. We used several starting materials (Table 1) corresponding to perovskite and ferropericlase. The hydrous composition was prepared by adding $\mathrm{Mg}(\mathrm{OH})_{2}$ or $\mathrm{Ca}(\mathrm{OH})_{2}$ to the synthetic mineral mixtures and adjusting the proportion of $\mathrm{MgO}$ and $\mathrm{CaO}$. A Kawai (MA8) multianvil 3000tons press of Tohoku University, Sendai was used in the experiments. The furnace assemblies and experimental details are described by Litasov and Ohtani (2002). Mineral compositions were measured by the electron microprobe under the operating condition of $15 \mathrm{kV}$ and $10 \mathrm{nA}$ current. Water contents were measured by FTIR. Infrared spectra were measured using Jasco MFT-2000 microsampling FTIR spectrometer (see Litasov et al., 2003, for more details of FTIR). The concentrations of hydroxyl groups were determined by the method of Paterson (1982) where absorption bands were integrated by using the calibration of the extinction coefficient and density factors.

\section{RESULTS}

The results of experiments are summarized in Table 1. Experimental products are represented by polycrystalline aggregates of major mineral according to the starting composition with minor amount of other phases. Selected electron microprobe analyses are shown in Table 2.

\section{MG-PEROVSKITE}

We measured water contents in four types of $\mathrm{Mg}$ perovskite samples: (1) pure $\mathrm{MgSiO}_{3}$ perovskite; (2) Al-rich $\mathrm{Mg}$-perovskite (denoted as Al-Mg-perovskite; $\left.\mathrm{Al}_{2} \mathrm{O}_{3}=2-7.2 \quad \mathrm{wt} \% ; \quad \mathrm{Mg} \#=\mathrm{Mg} /\left(\mathrm{Mg}+\mathrm{Fe}_{\text {total }}\right)=100\right)$; (3) $\mathrm{Mg}$-perovskite related to MORB (Al-Fe-Mg-perovskite; $\mathrm{Al}_{2} \mathrm{O}_{3}=13-17$ wt $\%$; $\mathrm{Mg \# =58-61);} \mathrm{and} \mathrm{(4)} \mathrm{Mg-}$ perovskite related to peridotite (Al-Fe-Mg-perovskite; $\mathrm{Al}_{2} \mathrm{O}_{3}=5-6 \mathrm{wt} \%$; $\mathrm{Mg} \#=88-90$ ). 
Table 1: Experimental results and water content of perovskites and ferropericlase.

\begin{tabular}{|c|c|c|c|c|c|c|}
\hline $\begin{array}{l}\text { Run } \\
\text { No. }\end{array}$ & Starting material & $\begin{array}{c}\text { Pressure } \\
(\mathrm{GPa})\end{array}$ & $\begin{array}{l}\text { Temp. } \\
\left({ }^{\circ} \mathrm{C}\right)\end{array}$ & $\begin{array}{l}\text { Time } \\
(\min )\end{array}$ & $\begin{array}{c}\text { Phase } \\
\text { Assemblage }\end{array}$ & $\begin{array}{c}\mathrm{H}_{2} \mathrm{O} \text { content } \\
\quad(\mathrm{ppm})^{2}\end{array}$ \\
\hline & Mg-perovskite & & & & & \\
\hline K-202 & $\mathrm{MgSiO}_{3}+10 \mathrm{wt} \% \mathrm{H}_{2} \mathrm{O}$ & 25 & 1300 & 360 & $\mathrm{MgPv}, \mathrm{L}$ & $104(14)$ \\
\hline $\mathrm{K}-200$ & $\mathrm{MgSiO}_{3}+10 \mathrm{wt} \% \mathrm{Al}_{2} \mathrm{O}_{3}+10 \mathrm{wt} \% \mathrm{H}_{2} \mathrm{O}$ & 25 & 1400 & 360 & Al-MgPv, Gt, L & $101(19)$ \\
\hline K-201 & $\mathrm{MgSiO}_{3}+10 \mathrm{wt} \% \mathrm{Al}_{2} \mathrm{O}_{3}$ & 25 & 1400 & 360 & Al-MgPv, Gt & \\
\hline K-165 & $\mathrm{Mg}_{2} \mathrm{SiO}_{4}+10 w t \% \mathrm{Al}_{2} \mathrm{O}_{3}+5 \mathrm{wt} \% \mathrm{H}_{2} \mathrm{O}$ & 25 & 1200 & 720 & Al-MgPv, Gt, NAL, L & $1101(156)$ \\
\hline K-164 & $\mathrm{Mg}_{2} \mathrm{SiO}_{4}+10 w t \% \mathrm{Al}_{2} \mathrm{O}_{3}+10 w t \% \mathrm{H}_{2} \mathrm{O}$ & 26 & 1200 & 900 & Al-MgPv, Gt, NAL, L & $1440(160)$ \\
\hline $\mathrm{K}-160$ & MORB Mg-perovskite ${ }^{1}+5 w t \% \mathrm{H}_{2} \mathrm{O}$ & 26 & 1000 & 1200 & Al-Fe-MgPv, L & $110(21)$ \\
\hline K-161 & same & 26 & 1200 & 900 & Al-Fe-MgPv, L & $104(26)$ \\
\hline K-208 & Peridotite Mg-perovskite ${ }^{1}+10 w t \% \mathrm{H}_{2} \mathrm{O}$ & 25 & 1400 & 360 & Al-Fe-MgPv, St, L & $1780(175)$ \\
\hline \multirow[t]{2}{*}{ K-209 } & same & 25 & 1600 & 120 & Al-Fe-MgPv, St, L & $1460(130)$ \\
\hline & Ca-perovskite & & & & & \\
\hline $\mathrm{K}-218$ & $\mathrm{CaSiO}_{3}+2 \mathrm{wt} \% \mathrm{Al}_{2} \mathrm{O}_{3}+10 \mathrm{wt} \% \mathrm{H}_{2} \mathrm{O}$ & 25 & 1600 & 120 & CaPv, NAL, L & $x^{3}$ \\
\hline \multirow[t]{2}{*}{$\mathrm{K}-227$} & same & 25 & 1900 & 30 & $\mathrm{CaPv}, \mathrm{L}$ & $\sim 5100$ \\
\hline & Ferropericlase & & & & & \\
\hline $\mathrm{K}-223$ & $\mathrm{MgO}+3 \mathrm{wt} \% \mathrm{Al}_{2} \mathrm{O}_{3}+10 \mathrm{wt} \% \mathrm{H}_{2} \mathrm{O}$ & 25 & 1400 & 120 & $\mathrm{Pc}, \mathrm{Br}$ & $21(8)$ \\
\hline $\mathrm{K}-220$ & same & 25 & 1600 & 120 & $\mathrm{Pc}, \mathrm{L}$ & $43(17)$ \\
\hline $\mathrm{K}-225$ & same & 25 & 1800 & 5 & $\mathrm{Pc}, \mathrm{L}$ & $112(21)$ \\
\hline $\mathrm{K}-216$ & $\left(\mathrm{Mg}_{0.88} \mathrm{Fe}_{0.12}\right) \mathrm{O}+3 \mathrm{wt} \% \mathrm{Al}_{2} \mathrm{O}_{3}+10 w t \% \mathrm{H}_{2} \mathrm{O}$ & 25 & 1400 & 360 & Fpc, Mst, L & $25(14)$ \\
\hline $\mathrm{K}-213$ & same & 25 & 1600 & 120 & Fpc, Mst, L & $71(23)$ \\
\hline $\mathrm{K}-224$ & same & 25 & 1800 & 20 & Fpc, L & $180(30)$ \\
\hline
\end{tabular}

Phases: MgPv, Mg-perovskite; Al-MgPv, aluminous Mg-perovskite; Al-Fe-MgPv, Al-Fe-Mg-perovskite; St, stishovite; NAL, $\mathrm{Na}-\mathrm{Al}$ phase; Gt, majorite garnet; $\mathrm{CaPv}$, Ca-perovskite; Pc, periclase; Br, brucite; Fpc, ferropericlase; Mst, magnesite; L, liquid. ${ }^{1}$ See table 2 for compositions; ${ }^{2} \mathrm{H}_{2} \mathrm{O}$ content for major mineral (Mg- and Ca-perovskite and ferropericlase) calculated by FTIR using method of Paterson (1982); ${ }^{3}$ The size of the crystals was not enough for FTIR measurements.

Unpolarized IR spectra of pure $\mathrm{MgSiO}_{3}$ perovskite synthesized at $25 \mathrm{GPa}$ and $1300^{\circ} \mathrm{C}$ are shown in Fig.1a. IR spectra show several bands: one major at $3448 \mathrm{~cm}^{-1}$ and three minor at 3397,3423 , and $3482 \mathrm{~cm}^{-1}$. The bands at 3423 and $3482 \mathrm{~cm}^{-1}$ are consistent with data reported by Meade et al. (1994) for $\mathrm{MgSiO}_{3}$ perovskite synthesized at $27 \mathrm{GPa}$ and $1830^{\circ} \mathrm{C}$. Calculated water content corresponds to about $100 \mathrm{ppm}_{2} \mathrm{O}$ (Table 1).

IR spectra of Al-Mg-perovskite containing $2 \mathrm{wt} \%$ of $\mathrm{Al}_{2} \mathrm{O}_{3}$ synthesized at $25 \mathrm{GPa}$ and $1400^{\circ} \mathrm{C}$ show a broad band near $3400 \mathrm{~cm}^{-1}$. The spectra are different from those of anhydrous perovskite (Fig.1b) and indicate water content near 100 ppm. Al-Mg-perovskite containing 4-7 wt.\% of $\mathrm{Al}_{2} \mathrm{O}_{3}$ shows broad IR spectra with poorly identified bands at 3404, 3448, and 3565 $\mathrm{cm}^{-1}$ (Fig. 1b). Calculated water content of single crystal perovskite in samples K-164 and K-165 is $1100-1400$ ppm.

The unpolarized spectra of MORB-related Al-Fe-Mgperovskite are shown in Fig.1c. The spectra are composed of two major bands at 3125 and $3397 \mathrm{~cm}^{-1}$ and some minor bands. The minor bands along with possible impurities can affect on broadening of the spectra. The nature of the band at $3125 \mathrm{~cm}^{-1}$ is not clear. We addressed this band to ringwoodite which has major $\mathrm{OH}$ vibration band at $3120 \mathrm{~cm}^{-1}$. The water content in MORB-related Al-Fe-Mg-perovskites measured using band at $3397 \mathrm{~cm}^{-1}$ is $90-110 \mathrm{ppm}$.

The unpolarized spectra of peridotite-related Al-Fe-Mgperovskite synthesized at $25 \mathrm{GPa}$ and $1400-1600^{\circ} \mathrm{C}$ are shown in Fig.1d. The spectra of thick $(80-120 \mu \mathrm{m})$ samples are broad and composed of two major bands at 3397 and $3690 \mathrm{~cm}^{-1}$. The position of major perovskite band at $3397 \mathrm{~cm}^{-1}$ is close to that determined by BolfanCasanova (2000) at $3388 \mathrm{~cm}^{-1}$. The band at $3690 \mathrm{~cm}^{-1}$ is absent in the spectra of thin crystals and may correspond to quench inclusions of brucite (which has a major band at $\left.3698 \mathrm{~cm}^{-1}\right)$. The band at $3690 \mathrm{~cm}^{-1}$ was not used in calculations of $\mathrm{H}_{2} \mathrm{O}$ content. The $\mathrm{H}_{2} \mathrm{O}$ content in $\mathrm{Mg}$-perovskite related to peridotite calculated for samples with average thickness is 1400-1800 ppm. 
Table 2: Average compositions of experimental phases.

\begin{tabular}{|c|c|c|c|c|c|c|c|c|c|c|c|c|c|}
\hline Sample & $\begin{array}{l}\mathrm{K}-202 \\
\mathrm{MgPv}\end{array}$ & $\begin{array}{c}\mathrm{K}-200 \\
\mathrm{Al}- \\
\mathrm{MgPv}\end{array}$ & $\begin{array}{c}\mathrm{K}-201 \\
\mathrm{Al}- \\
\mathrm{MgPv}\end{array}$ & $\begin{array}{c}\mathrm{K}-164 \\
\mathrm{Al}- \\
\mathrm{MgPv}\end{array}$ & $\begin{array}{l}\mathrm{K}-160 \\
\mathrm{MgPv} \\
\text { (bas.) }\end{array}$ & $\begin{array}{l}\mathrm{K}-161 \\
\mathrm{MgPv} \\
\text { (bas.) }\end{array}$ & $\begin{array}{l}\mathrm{K}-208 \\
\mathrm{MgPv} \\
\text { (per.) }\end{array}$ & $\begin{array}{l}\mathrm{K}-209 \\
\mathrm{MgPv} \\
\text { (per.) }\end{array}$ & $\begin{array}{l}\mathrm{K}-227 \\
\mathrm{CaPv}\end{array}$ & $\begin{array}{l}\mathrm{K}-218 \\
\mathrm{CaPv}\end{array}$ & $\begin{array}{c}\mathrm{K}-216 \\
\mathrm{Fpc}\end{array}$ & $\begin{array}{c}\mathrm{K}-213 \\
\mathrm{Fpc}\end{array}$ & $\begin{array}{c}\mathrm{K}-224 \\
\mathrm{Fpc}\end{array}$ \\
\hline $\mathrm{SiO}_{2}$ & 60.10 & 59.09 & 59.19 & 55.37 & 36.73 & 38.11 & 52.77 & 53.11 & 48.92 & 49.24 & & & \\
\hline $\mathrm{TiO}_{2}$ & & & & & 2.18 & 1.91 & & & & & & & \\
\hline $\mathrm{Al}_{2} \mathrm{O}_{3}$ & & 2.03 & 1.45 & 7.16 & 14.50 & 13.16 & 5.50 & 5.80 & 2.08 & 1.49 & 0.90 & 1.65 & 2.00 \\
\hline $\mathrm{FeO}^{*}$ & & & & & 26.23 & 24.52 & 7.39 & 6.09 & & & 17.39 & 18.09 & 18.11 \\
\hline $\mathrm{MgO}$ & 40.36 & 39.77 & 39.78 & 38.14 & 20.15 & 21.37 & 34.48 & 34.94 & & & 80.81 & 81.94 & 80.30 \\
\hline $\mathrm{CaO}$ & & & & & & & & & 47.67 & 47.33 & & & \\
\hline $\mathrm{H}_{2} \mathrm{O}^{*}$ & 0.01 & 0.01 & & 0.14 & 0.01 & 0.01 & 0.18 & 0.15 & 0.50 & 0.50 & 0.00 & 0.01 & 0.02 \\
\hline Total & 100.5 & 100.9 & 100.4 & 100.8 & 99.81 & 99.08 & 100.3 & 100.1 & 99.17 & 98.56 & 99.10 & 101.6 & 100.4 \\
\hline $\mathrm{Si}$ & 1.000 & 0.979 & 0.985 & 0.918 & 0.683 & 0.709 & 0.903 & 0.907 & 0.951 & 0.962 & & & \\
\hline $\mathrm{Ti}$ & & & & & 0.031 & 0.027 & & & & & & & \\
\hline $\mathrm{Al}$ & & 0.039 & 0.028 & 0.140 & 0.319 & 0.289 & 0.111 & 0.117 & 0.048 & 0.034 & 0.008 & 0.014 & 0.017 \\
\hline${ }^{\$} \mathrm{Fe}^{3+}$ & & & & & 0.245 & 0.229 & 0.063 & 0.052 & & & & & \\
\hline $\mathrm{Fe}^{2+}$ & & & & & 0.163 & 0.153 & 0.042 & 0.035 & & & 0.106 & 0.108 & 0.109 \\
\hline $\mathrm{Mg}$ & 1.000 & 0.982 & 0.987 & 0.942 & 0.559 & 0.593 & 0.880 & 0.889 & & & 0.882 & 0.871 & 0.865 \\
\hline $\mathrm{Ca}$ & & & & & & & & & 0.993 & 0.991 & & & \\
\hline Total & 2.000 & 2.000 & 2.000 & 2.000 & 2.000 & 2.000 & 2.000 & 2.000 & 2.010 & 2.008 & 0.996 & 0.993 & 0.991 \\
\hline $\mathrm{H}$ & 0.001 & 0.001 & & 0.015 & 0.001 & 0.001 & 0.021 & 0.017 & 0.065 & 0.065 & 0.000 & 0.001 & 0.002 \\
\hline $2 V_{0}$ & & 0.003 & 0.002 & 0.025 & 0.008 & 0.010 & 0.019 & 0.017 & 0.042 & 0.029 & & & \\
\hline $\mathrm{Mg} \#$ & & & & & 57.8 & 60.8 & 89.3 & 91.1 & & & 89.2 & 89.0 & 88.8 \\
\hline
\end{tabular}

$\mathrm{FeO}^{*}$, total $\mathrm{Fe}$ as $\mathrm{FeO} . \mathrm{Mg} \#=100 \mathrm{Mg} /\left(\mathrm{Mg}^{2} \mathrm{Fe}_{\text {total }}\right) . \mathrm{H}_{2} \mathrm{O}^{*}$, suggested $\mathrm{H}_{2} \mathrm{O}$ content from Table $1 .{ }^{\$} \mathrm{Fe}^{3+}$ was calculated from $\mathrm{Fe}^{3+} / \Sigma \mathrm{Fe}$ ratio by EELS (Litasov et al., 2003). $2 \mathrm{~V}_{\mathrm{O}}=(1-\mathrm{Si}-\mathrm{Ti})-\left(1-\mathrm{Mg}-\mathrm{Fe}^{2+}{ }^{2+} \mathrm{Ca}\right)=\mathrm{M}^{3+}{ }_{\mathrm{B}}-\mathrm{M}^{3+}{ }_{\mathrm{A}}$, is amount of oxygen vacancies in $\mathrm{ABO}_{3}$-perovskite, which can be filled by hydrogen atoms. Bas., MORB; Per., peridotite. See table 1 for other abbreviations.

\section{CA-PEROVSKITE}

The unpolarized spectra of aluminous Ca-perovskite synthesized at $25 \mathrm{GPa}$ and $1900^{\circ} \mathrm{C}$ are shown in Fig.2. The spectra composed of two major bands at 3343 and $3607 \mathrm{~cm}^{-1}$. The $\mathrm{H}_{2} \mathrm{O}$ content in Ca-perovskite is near 5100 ppm. Ca-perovskite contain more $\mathrm{Al}_{2} \mathrm{O}_{3}$ with increasing temperature, therefore water solubility may increase also.

\section{FERROPERICLASE}

IR spectra of periclase show weak bands at 3299, 3308, and $3404 \mathrm{~cm}^{-1}$. Ferropericlase has major bands at 3299 and $3474 \mathrm{~cm}^{-1}$ (Fig.3). Calculated $\mathrm{H}_{2} \mathrm{O}$ content in periclase is $21 \mathrm{ppm}$ at $1400^{\circ} \mathrm{C}\left(\mathrm{Al}_{2} \mathrm{O}_{3}\right.$ in periclase is 0.7 $\mathrm{wt} \%)$ and $112 \mathrm{ppm}$ at $1800^{\circ} \mathrm{C}\left(\mathrm{Al}_{2} \mathrm{O}_{3}=1.2 \mathrm{wt} \%\right)$. The $\mathrm{H}_{2} \mathrm{O}$ content in ferropericlase is $25 \mathrm{ppm}$ at $1400^{\circ} \mathrm{C}$ $\left(\mathrm{Al}_{2} \mathrm{O}_{3}=1.0 \mathrm{wt} \%\right)$ and $180 \mathrm{ppm}$ at $1800^{\circ} \mathrm{C}\left(\mathrm{Al}_{2} \mathrm{O}_{3}=2.2\right.$ $\mathrm{wt} \%$ ). These data indicate that (1) ferropericlase $(\mathrm{Mg} \#=88)$ contains more water and $\mathrm{Al}_{2} \mathrm{O}_{3}$ relative to periclase and (2) water content in ferropericlase increases with increasing temperature and $\mathrm{Al}_{2} \mathrm{O}_{3}$.

\section{DISCUSSION}

\section{STRUCTURAL POSITION OF WATER}

Substitution of $\mathrm{Al}$ or $\mathrm{Fe}^{3+}$ for $\mathrm{Si}$ in perovskite and $\mathrm{Mg}$ in periclase can create oxygen defects, which potentially absorb hydrogen. Therefore, $\mathrm{H}_{2} \mathrm{O}$ solubility increases with increasing $\mathrm{Al}^{3+}$ or $\mathrm{Fe}^{3+}$ content. This is not true for $\mathrm{Al}$-and Fe-rich Mg-perovskite related to MORB. The defect equilibria in perovskites are dominated by the following substitution in $\mathrm{A}^{2+} \mathrm{B}^{4+} \mathrm{O}_{3}$ (Navrotsky, 1999):

$2 \mathrm{Si}^{4+}{ }_{\mathrm{B}}=2 \mathrm{M}^{3+}{ }_{\mathrm{B}}+\mathrm{V}_{\mathrm{O}}$

$\mathrm{V}_{\mathrm{O}}+\mathrm{O}^{2-}{ }_{\mathrm{O}}+\mathrm{H}_{2} \mathrm{O}=2 \mathrm{OH}_{\mathrm{O}}^{-}$

where subscripts $\mathrm{O}$ and $\mathrm{B}$ denote oxygen and $\mathrm{B}$-cation sites respectively and $\mathrm{M}^{3+}=\mathrm{Al}^{3+}$ or $\mathrm{Fe}^{3+}$. Eq. (1) creates oxygen vacancies, $V_{O}$, which can be and eq. (2) fills them. Incorporation of trivalent cations such as $\mathrm{Al}$ and Fe into $\mathrm{MgSiO}_{3}$ perovskite can follow a coupled substitution of two trivalent ions for silicon and magnesium according to $\mathrm{Mg}^{2+}{ }_{\mathrm{A}}+\mathrm{Si}^{4+}{ }_{\mathrm{B}}=\mathrm{M}^{3+}{ }_{\mathrm{A}}+\mathrm{M}^{3+}{ }_{\mathrm{B}}$ (3).

The EELS spectra of Al-Fe-Mg-perovskite related to MORB indicate that it contains a large amount of ferric 

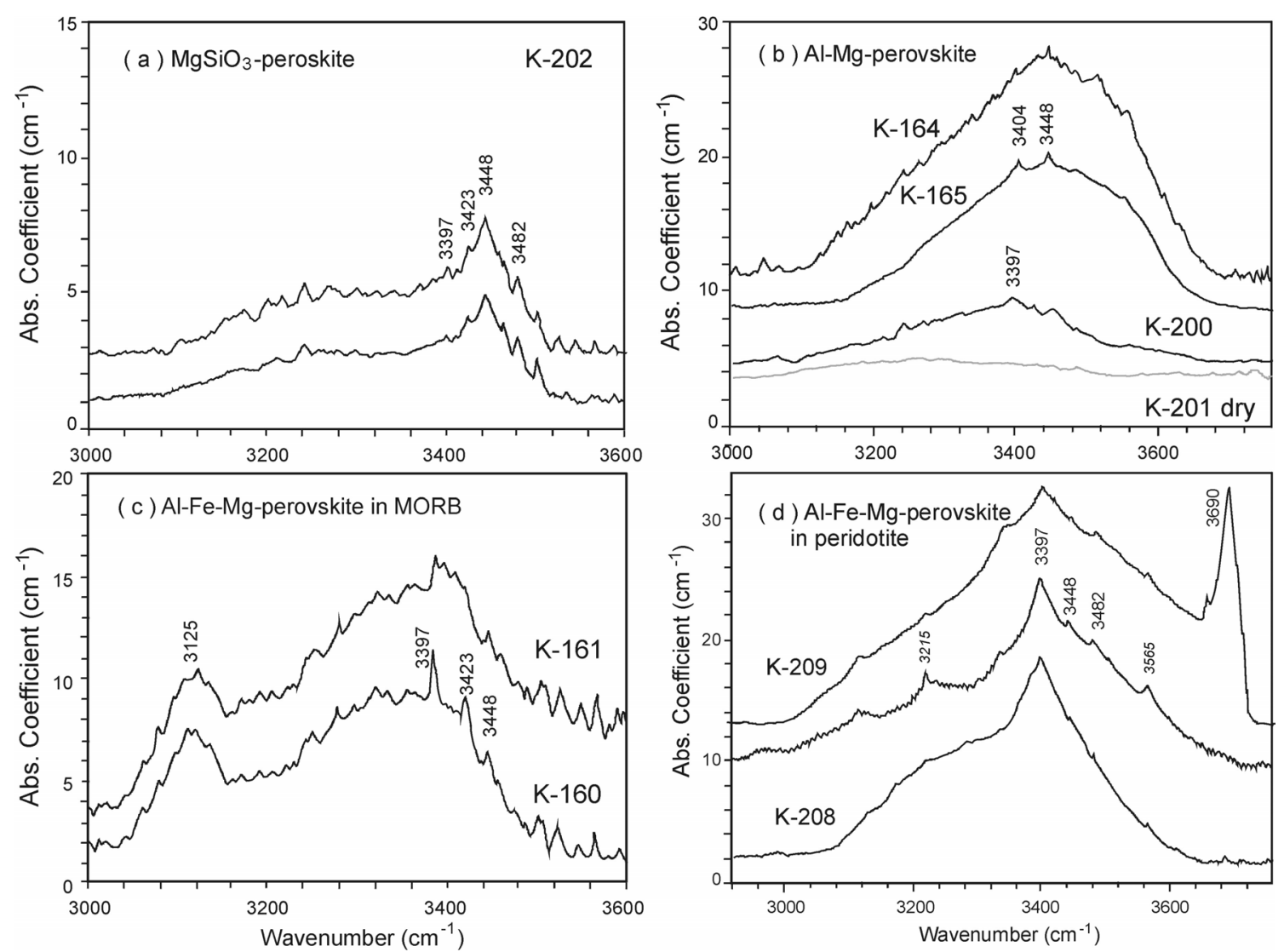

Figure 1: Examples of unpolarized FTIR spectra of Mg-perovskite synthesized at 25-26 GPa.

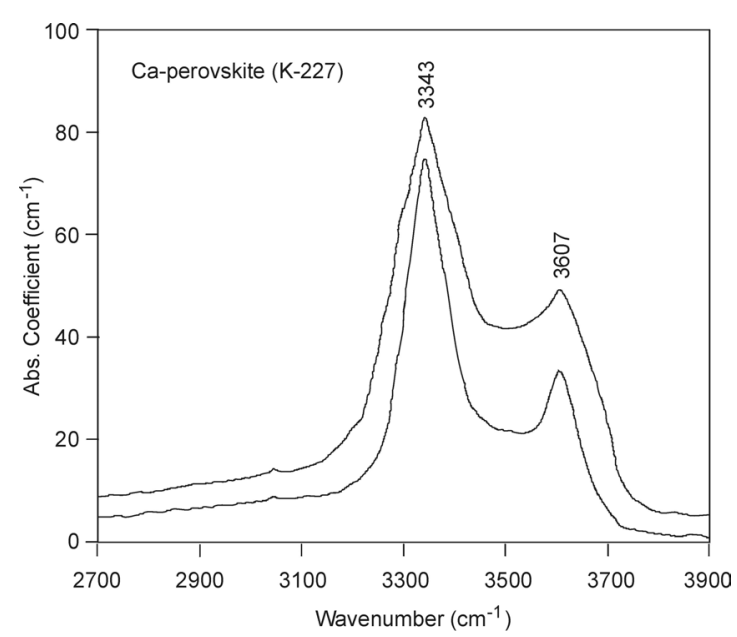

Figure 2: Examples of unpolarized FTIR spectra of Caperovskite synthesized at $25 \mathrm{GPa}$ and $1900^{\circ} \mathrm{C}$.

iron, $\mathrm{Fe}^{3+} / \Sigma \mathrm{Fe} \approx 0.6$ (Litasov et al., 2003). Therefore, trivalent cations favors substitution of $\mathrm{Mg}$ and $\mathrm{Si}$ sites by the mechanism of eq.3. In MORB-related perovskite only $2-4 \%$ of trivalent cations in site B create oxygen vacancies by Eq.1. This evidence explains restricted water solubility in MORB Mg-perovskite, which contains less than 0.010 p.f.u. of oxygen vacancies (Table 2). The cation values of peridotite $\mathrm{Mg}$ perovskite (samples K-208 and K-209 in Table 2) indicate that $12-20 \%$ of the $\mathrm{M}^{3+}$ cations in site $\mathrm{B}$ create 0.012-0.017 p.f.u. oxygen vacancies according to Eq.1.

The cation values of Ca-perovskite indicate that most of Al occupies Si site creating oxygen vacancies. However, $\mathrm{H}_{2} \mathrm{O}$ content in Ca-perovskite is higher than the amount of vacancies (Table 2). This indicates that other substituions are involved for hydroxyl incorporation in Ca-perovskite.

The $\mathrm{Al}_{2} \mathrm{O}_{3}$ impurity can create oxygen vacancies in ferropericlase by substitution of two $\mathrm{Mg}$ atoms. However, water solubility in ferropericlase related to natural fertile peridotite, is restricted. This is consistent with data by Bolfan-Casanova et al. (2002). Ferropericlase can not be considered as important water reservoir in the lower mantle. It is important to note that 
increase of $\mathrm{H}_{2} \mathrm{O}$ solubility in ferropericlase with increasing temperature (and $\mathrm{Al}_{2} \mathrm{O}_{3}$ ) may be very important for water distribution in the lower mantle.

\section{WATER STORAGE CAPASITY OF THE LOWER MANTLE}

The present results indicate that Ca-perovskite has highest water solubility among the lower mantle minerals following by Mg-perovskite and ferropericlase.
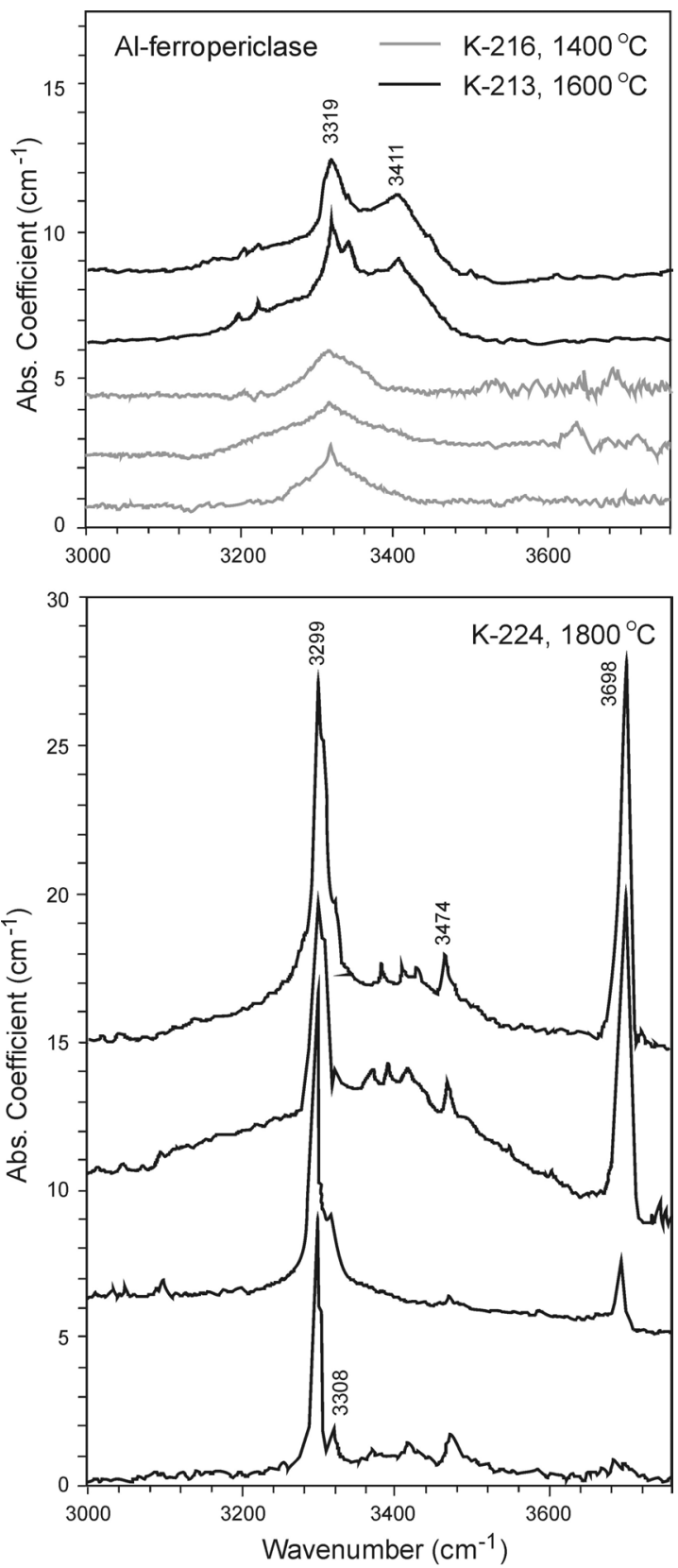

Figure 3: Examples of unpolarized FTIR spectra of ferropericlase synthesized at $25 \mathrm{GPa}$.
Average fertile lower mantle peridotite consists of 80 $\mathrm{wt} \%$ of Mg-perovskite, $15 \mathrm{wt} \%$ ferropericlase, and 5 $w t \%$ of Ca-perovskite. Taking into account possible decrease of water content in the phases with increasing temperature up to the mantle geotherm, we can estimate that the average lower mantle peridotite can contain 0.12 wt. $\%$ of $\mathrm{H}_{2} \mathrm{O}$. Therefore, the maximum amount of water in the lower mantle is estimated as $3.62 \times 10^{21} \mathrm{~kg}$. This is 2.6 times of the present ocean mass and comparable with the amount of water potentially concentrated in the transition zone. This indicates that lower mantle can produce hydrous fluid for arising mantle plumes. Hydrous conditions increase transport ability of the plume materials and, therefore, facilitate delivery of the lower mantle diamonds to the lithosphere.

\section{REFERENCES}

Bolfan-Casanova, N., Keppler, H., Rubie, D., 2000. Water partitionong between nominally anhydrous minerals in the $\mathrm{MgO}-\mathrm{SiO}_{2}-\mathrm{H}_{2} \mathrm{O}$ system up to $24 \mathrm{GPa}$ : implications for the distribution of water in the Earth's mantle. Earth Planet. Sci. Lett. 182, 209-221.

Bolfan-Casanova, N., Mackwell, S., Keppler, H., McCammon, C., Rubie, D., 2002. Pressure dependence of $\mathrm{H}$ solubility in magnesiowustite up to $25 \mathrm{GPa}$ : Implications for the storage of water in the Earth's lower mantle. Geophys. Res. Lett. 29, 10.1029/2001GL014457.

Kohlstedt, D.L., Keppler, H., Rubie, D.C., 1996. Solubility of water in the $\alpha, \beta$, and $\gamma$ phases of $(\mathrm{Mg}, \mathrm{Fe})_{2} \mathrm{SiO}_{4}$. Contrib. Mineral. Petrol. 123, 345-357.

Litasov, K., Ohtani, E., 2002. Phase relations and melt compositions in CMAS-pyrolite- $\mathrm{H}_{2} \mathrm{O}$ system up to 25 GPa, Phys. Earth Planet. Inter. 134, 105-127.

Litasov, K., Ohtani, E., Langenhorst, F., Yurimoto, H., Kubo, T., Kondo, T, 2003. Water Solubility in Mgperovskites and Water Storage Capacity in the Lower Mantle. Earth Planet. Sci. Lett., submitted.

Meade, C., Reffner, J.A., Ito, E., 1994. Synchrotron infrared absorbance measurements of hydrogen in $\mathrm{MgSiO}_{3}$ perovskite. Science 264, 1558-1560.

Murakami, M., Hirose, K., Yurimoto, H., Nakashima, S., Takafuji, N., 2002. Water in Earth's lower mantle, Science 295, 1885-1887.

Navrotsky, A., 1999. Mantle geochemistry: A lesson from ceramics. Science 284, 1788

Paterson, M.S., 1982. The determination of hydrohyl by infrared absorption in quartz, silicate glasses and similar materials. Bull. Mineral. 105, 20-29.

Ringwood, A.E., 1977. Composition of the core and implications for origin of the earth. Geochem. Jour. 11, 111-135.

Contact: KD Litasov, Inst. Mineral. Petrol. Econ. Geol.,

Tohoku Univ., Sendai, 980-8578, Japan, E-mail:

klitasov@ganko.tohoku.ac.jp 